\title{
Physical Mapping of the Cystic Fibrosis Region by Pulsed-Field Gel Electrophoresis
}

\author{
Mitchell L. Drumm, ${ }^{\star}$ Cassandra L. Smith, $\dagger$ Michael Dean, $\ddagger$ Jeffery L. Cole, ${ }^{*}$ \\ Michael C. Iannuzzi, ${ }^{\star}$ and Francis S. Collins* \\ *Departments of Internal Medicine and Human Genetics and the Howard Hughes Medical Institute, University of Michigan, \\ Ann Arbor, Michigan 48109; †Departments of Microbiology and Psychiatry, Columbia University College of Physicians and \\ Surgeons, New York, New York 10032; and $\ddagger$ Biological Carcinogenesis Development Program, Program Resource Incorporated, \\ Frederick Cancer Research Facility, Frederick, Maryland 21701
}

Received December 9, 1987; revised March 21, 1988

\begin{abstract}
The gene for cystic fibrosis (CF) is known to be flanked by the closely linked DNA markers met and J3.11 on chromosome 7. Using the technique of pulsed-field gel electrophoresis, we have constructed a complete overlapping restriction map of approximately $3000 \mathrm{~kb}$ of DNA in this region. The met and J3.11 probes are found to be between 1300 and 1800 kb apart, which compares well with their genetic distance of 1-2 cM. The CF gene must be located within this interval, and the availability of this physical map should be of considerable utility in mapping additional clones as the search for the gene proceeds. (c) 1988 Academic Press, Inc.
\end{abstract}

\section{INTRODUCTION}

Cystic fibrosis (CF) is the most common autosomal recessive disease in the Caucasian population, affecting approximately 1 in 2000 newborns. CF is characterized by chronic pulmonary disease, pancreatic insufficiency, elevated sweat chloride levels, and sterility in males (Lloyd-Still, 1983). Decades of research at the biochemical and physiologic levels have thus far failed to reveal the nature of the metabolic defect, though recent evidence indicates that the abnormality may lie in a failure of chloride channel responsiveness to adrenergic stimuli (Frizzell et al., 1986; Welsh and Liedtke, 1986).

Because of the difficulty in defining the metabolic abnormality by a direct approach, considerable excitement has been generated recently by the application of "reverse genetics" to the CF problem. In this approach the gene is sought not by knowledge of its function, but by its map position (Ruddle, 1984; Orkin, 1986). Such an approach has recently been successful in identifying the genes for chronic granulomatous disease (Royer-Pokora et al., 1986), Duchenne muscular dystrophy (Monaco et al., 1986), and retinoblastoma (Friend et al., 1986).

The first step in this procedure is the localization of the gene to a particular chromosome by linkage analysis; this was accomplished for CF 2 years ago by identification of linkage to an anonymous marker DOCR-917 on chromosome 7q (Tsui et al., 1985). Analysis of CF families with other markers on chromosome 7 subsequently demonstrated that two markers lie within $1 \mathrm{cM}$ of the gene: the met protooncogene (White et al., 1985) and the random probe J3.11 (Wainwright et al., 1985). Recent multipoint analysis has shown that the odds in favor of CF lying in between these two markers are very high (Beaudet et al., 1986; Lathrop et al., 1987). This delimits the location of the CF gene to a region of approximately 2 $\mathrm{cM}$; on the average, this should represent about 2000 $\mathrm{kb}$ of physical distance (Smith et al., 1987b). Two factors make this only a rough estimate, however: the width of the $95 \%$ confidence limits on the met-J3.11 linkage distance, and the variability in the relationship between genetic distance and physical distance.

Other markers in this interval have subsequently been cloned. Using the technique of chromosome jumping (Collins and Weissman, 1984; Poustka and Lehrach, 1986), we obtained a clone called CF63 which is approximately $100 \mathrm{~kb} 3^{\prime}$ to the met gene (Collins et al., 1987a), in the direction of CF (see below for evidence of directionality of the met gene in this region). By selection for clones rich in hypomethylated CpG sequences, Estivill et al. (1987) obtained DNA fragments XV-2c and CS.7, which lie between met and J3.11 by linkage analysis and which detect restriction fragment length polymorphisms (RFLPs) in strong linkage disequilibrium with the CF mutation.

Linkage disequilibrium indicates that most CF is likely due to a mutant allele with a single origin. It is 
difficult, however, to use this information to precisely delimit the location of the $\mathrm{CF}$ gene, since disequilibrium may not be a linear function of proximity to the gene. In this situation, it is essential to develop a physical map of the region so that the limits of the region of candidate genes can be fully defined and in order to develop signposts in the area which can be used to unequivocally order probes on the chromosome.

The recent development of pulsed-field gel electrophoresis ( Schwartz et al., 1983; Schwartz and Cantor, 1984; Carle and Olson, 1984; Carle et al., 1986; Cantor et al., 1986; Chu et al., 1986) has made possible the construction of long-range physical maps by providing the means to separate DNA fragments as large as $10,000 \mathrm{~kb}$. When combined with restriction enzymes which cut only rarely in the genome and Southern blotting techniques to identify single-copy fragments in complete and partial digests, this approach provides a means of constructing a map of a region of several megabases (Smith et al., 1986, 1987b; Smith and Cantor, 1987). This has been recently accomplished in man, for example, for the Duchenne muscular dystrophy region (van Ommen et al., 1986; Burmeister and Lehrach, 1986; Kenwrick et al., 1987), the major histocompatibility complex (Lawrance et al., 1987), the human $\beta$-globin region (Collins et al., $1987 \mathrm{~b}$ ), and regions of chromosome $4 \mathrm{p}$ near the Huntington disease locus (Poustka et al., 1987). We have now applied this approach to the CF region, using met, CF63, and J3.11 as molecular probes. A detailed restriction map has been constructed with a variety of enzymes which cut rarely in genomic DNA, and the CF gene has been localized to a region of approximately $1800 \mathrm{~kb}$.

\section{MATERIALS AND METHODS}

\section{DNA Preparation}

DNA was prepared essentially as described by Smith et al. (1986). Briefly, human lymphoblastoid cells from cell line 3.1.0 were harvested by centrifugation at $120 \mathrm{~g}$ for $5 \mathrm{~min}$, washed once with phosphatebuffered saline (PBS), and then resuspended to a concentration of $2 \times 10^{7}$ cells $/ \mathrm{ml}$. The cells were warmed to $50^{\circ} \mathrm{C}$ and mixed with an equal volume of molten Sea Plaque (FMC) low-melting-temperature agarose, which was $2 \%$ in $125 \mathrm{mM}$ EDTA. The mixture was then cast into $0.1-\mathrm{ml}$ blocks, which were cooled and placed into lysis solution at a concentration of $1.5 \mathrm{blocks} / \mathrm{ml}$ of solution. Lysis solution was $1 \% N$-lauroylsarcosine (Sigma), 0.5 $M$ EDTA, pH 8, and $0.5 \mathrm{mg} / \mathrm{ml}$ proteinase $\mathrm{K}$. Blocks were incubated for $6 \mathrm{~h}$ at $50^{\circ} \mathrm{C}$, and incubation was repeated twice with fresh lysis solution. After lysis, the blocks were rinsed several times with TE ( $10 \mathrm{~m} M$ Tris, $\mathrm{pH} 7.5,1$
mM EDTA) and then incubated at room temperature with gentle rocking in two changes of TE with $1 \mathrm{mM}$ phenylmethylsulfonyl fluoride (PMSF), each for $2 \mathrm{~h}$. Blocks were then rinsed several times with TE and stored at $4^{\circ} \mathrm{C}$.

\section{Restriction Digests}

One-third of a block, or approximately $3 \mu \mathrm{g}$ of DNA, was digested by adding the block to $25 \mu \mathrm{l}$ of $10 \times$ restriction enzyme buffer, $190 \mu \mathrm{l}$ of water, and 15 to 20 $\mathrm{U}$ of enzyme. Digests were carried out for $2 \mathrm{~h}$ at $37^{\circ} \mathrm{C}$. Enzymes were from New England Biolabs (Beverly, MA).

\section{Electrophoresis, Blotting, and Hybridization}

All gels were $1 \%$ agarose in $0.5 \mathrm{X}$ Tris-borateEDTA (Maniatis et al., 1982) as electrophoresis buffer. Field-inversion gels (Carle et al., 1986) were run using ramping programmed by a DNAStar Pulse unit (Madison, WI) for $65 \mathrm{~h}$ at $165 \mathrm{~V}$; forward times ranged linearly from 6 to $240 \mathrm{~s}$, and the ratio of forward to reverse times was always $3: 1$. Orthogonal field (OFAGE) gels were run on an apparatus constructed according to Carle and Olson (1984) for $20 \mathrm{~h}$ and a pulse time of $40 \mathrm{~s}$. Separation of fragments above 1000 $\mathrm{kb}$ was carried out using the LKB Pulsaphor (LKBPharmacia, Houston) for 5 to 7 days at $95 \mathrm{~V}$, with a pulse time of 30 to $70 \mathrm{~min}$.

After electrophoresis, gels were exposed to $1 \mathrm{~min}$ of 254-nm uv light on a transilluminator box and then soaked in $0.5 \mathrm{M} \mathrm{NaOH}, 1.5 \mathrm{M} \mathrm{NaCl}$ for $20 \mathrm{~min}$. Capillary blotting to GeneScreen (DuPont) was carried out for $30 \mathrm{~h}$ using $0.5 \mathrm{M} \mathrm{NaOH}, 1.5 \mathrm{M} \mathrm{NaCl}$ as the transfer solution. The blots were neutralized in $1 M$ ammonium acetate, $20 \mathrm{mM} \mathrm{NaOH}$ for $5 \mathrm{~min}$, air-dried for $6 \mathrm{~h}$, and baked $20 \mathrm{~min}$ under vacuum at $80^{\circ} \mathrm{C}$, and then the DNA was uv-crosslinked to the filter by a 1.5 -min exposure to a $330-\mathrm{nm}$ light source. This protocol is similar to one described by Herrmann et al. (1986).

Probes were labeled by the random priming method of Feinberg and Vogelstein (1984), boiled, and then preannealed for 90 min with a 5000 -fold excess (w/w) of sonicated human genomic DNA (Litt and White, 1985).

Hybridizations were carried out using a modification of the Church and Gilbert (1984) protocol for genomic sequencing. Blots were prehybridized at $65^{\circ} \mathrm{C}$ for $1 \mathrm{~h}$ in $15 \mathrm{ml}$ of $0.5 \mathrm{M}$ sodium phosphate $\mathrm{pH}$ 7.2), 7\% SDS, and $1 \mathrm{mM}$ EDTA ( $1 M$ sodium phosphate is $134 \mathrm{~g} \mathrm{NaH}_{2} \mathrm{PO}_{4} \cdot 7 \mathrm{H}_{2} \mathrm{O}$ and $4 \mathrm{ml}$ phosphoric acid per liter). Probes were added to sealed bags and hybridization was carried out for 24 to $36 \mathrm{~h}$ at $65^{\circ} \mathrm{C}$. Washes were $3 \times 15 \mathrm{~min}$ with $40 \mathrm{mM}$ sodium phosphate, $0.5 \%$ SDS, $1 \mathrm{mM}$ EDTA, at $65^{\circ} \mathrm{C}$ with shaking. 
Blots were routinely stripped by preheating $1 \mathrm{mM}$ Tris, pH 8, $0.1 \mathrm{~m} M$ EDTA, $1 \%$ SDS to $80^{\circ} \mathrm{C}$, adding this to filters, and incubating at $65^{\circ} \mathrm{C}$ for $20 \mathrm{~min}$ with shaking. Filters were rinsed with water and placed against X-ray film for 20-24 h to show that stripping was complete.

\section{RESULTS}

The following probes were used to construct the maps: metH, CF63, and 3.11H3. metH is a subclone from the $3^{\prime}$ end of met (White et al., 1985); CF63 is a clone derived by chromosome jumping (Collins et al., 1987a), mapping approximately $100 \mathrm{~kb}$ further $3^{\prime}$ to metH; and 3.11H3, also referred to as p3H-3 (Dean et al., 1987), was isolated from a $\lambda$ clone hybridizing to $\mathrm{J} 3.11$ and is a $2.5-\mathrm{kb}$ HindIII fragment mapping $2.7 \mathrm{~kb}$ from J3.11 (D7S8, Wainwright et al., 1985). These probes were used to screen genomic digest blots, and the resultant fragment sizes for single enzyme digests, including partial cleavage products, are listed in Table 1 ; fragment sizes for double digests are listed in Table 2.

Separate maps of the met and D7S8 regions were first constructed and these two maps were then linked together in order to construct a map spanning the region between metH and J3.11.

\section{metH/CF63 map}

Using metH as a probe and a combination of NotI complete and $S f i$ partial digests, a 140 -kb $S f i$ fragment is generated (Fig. 1). In $S f I$ partial digests, the most prominent partial bands are at 165 and $560 \mathrm{~kb}$. This suggests that the $140-\mathrm{kb} S f i$ fragment is flanked by a $25-\mathrm{kb} S f i$ fragment on one side and a $420-\mathrm{kb}$ fragment on the other side. With an SfI + NotI double digest, the $560-\mathrm{kb}$ band disappears and a doublet of 320 and $345 \mathrm{~kb}$ appears, indicating that a NotI site is present in the $420-\mathrm{kb} S f \mathrm{I}$ fragment. With this information, the map shown in Fig. 1 can be readily constructed. With this map as a foundation, other restriction sites were added using the data in Tables 1 and 2. Representative lanes of a single FIGE blot probed with metH, CF63, and $3.11 \mathrm{H3}$ are shown in Fig. 2.

CF63 detects a 35-kb $S f i$ primary fragment and a 60 -kb SfiI partial fragment (Fig. 2B). Because both CF63 and metH detect NruI fragments of 115 and 135 $\mathrm{kb}$, we therefore conclude that the probes are no more than $115 \mathrm{~kb}$ apart and are most likely separated by a single 25 -kb $S f I$ fragment. The 115 -kb primary and 135-kb partial $\mathrm{NruI}$ fragments detected by both metH and CF63 are cleaved by SfiI to $65-$ and $85-\mathrm{kb}$ fragments detected by metH and a $30-\mathrm{kb}$ fragment detected by CF63, placing the SfiI sites relative to the $\mathrm{NruI}$ sites as shown in Fig. 3A. These same NruI fragments are cleaved by $M l u I$ to give $60-$ and $80-\mathrm{kb}$ fragments for metH and $55 \mathrm{~kb}$ for CF63. The placement of MluI sites with respect to NruI sites is shown in Fig. 3B. The 560-kb Sfi partial band detected by metH is cut by $M l u \mathrm{I}$, reducing it to $300 \mathrm{~kb}$, the same size fragment as generated by $M l u I$ alone. When CF63 is used as the probe, the pattern of bands is identical to $S f i \mathrm{I}$ alone, in which a $35-$ and a $60-\mathrm{kb}$ band are detected. This would suggest that the MluI site separating metH and $\mathrm{CF} 63$ is extremely close to an $S f i \mathrm{I}$ site and gives the map shown in Fig. 3C, the same map which is predicted by superimposing Fig. 3A on Fig. 3B.

No difference between the digestion products of BssHII, SacII, and NaeI has been observed on blots

TABLE 1

Sizes (in kb) of Restriction Fragments Generated by the Enzymes Listed and Detected by the Probes Given

\begin{tabular}{|c|c|c|c|c|c|c|c|c|c|}
\hline \multirow[b]{2}{*}{ Probe } & \multicolumn{9}{|c|}{ Enzyme } \\
\hline & BssHII & MluI & NaeI & Not I & NruI & SacII & SalI & $S f i \mathrm{I}$ & XhoI \\
\hline metH & $\begin{array}{l}240 \\
400\end{array}$ & $\begin{array}{r}300 \\
460 \\
1250 \\
2250\end{array}$ & $\begin{array}{l}240 \\
400\end{array}$ & 850 & $\begin{array}{r}115 \\
135 \\
1815\end{array}$ & $\begin{array}{l}240 \\
400\end{array}$ & 630 & $\begin{array}{l}140 \\
165 \\
560 \\
585\end{array}$ & 550 \\
\hline CF63 & $\begin{array}{l}240 \\
400\end{array}$ & $\begin{array}{r}950 \\
1250 \\
2250\end{array}$ & $\begin{array}{l}240 \\
400\end{array}$ & 850 & $\begin{array}{r}115 \\
135 \\
1815\end{array}$ & $\begin{array}{l}240 \\
400\end{array}$ & ND & $\begin{array}{r}35 \\
60 \\
140\end{array}$ & 550 \\
\hline $3.11 \mathrm{H} 3$ & 1200 & $\begin{array}{l}1000 \\
1950 \\
2250\end{array}$ & $\mathrm{ND}$ & 5000 & $\begin{array}{l}1700 \\
1815\end{array}$ & 1000 & 160 & 1050 & 120 \\
\hline
\end{tabular}

Note. For each digest, the smallest fragment is assumed to be a complete digestion product, while those listed below it are partial cleavage products. All digests were considered complete for this cell line, since neither increased enzyme amount nor incubation time altered hybridization patterns of probes from those listed here. Sizes of the largest partial cleavage products, which are difficult to size accurately, are estimated on the basis of addition of the sizes of primary fragments. 
PHYSICAL MAP OF CF REGION

TABLE 2

Cleavage Products (in kb) from Double Enzyme Digestions

\begin{tabular}{|c|c|c|c|c|c|c|c|c|}
\hline \multirow[b]{2}{*}{ Probe } & \multicolumn{8}{|c|}{ Enzymes } \\
\hline & $\begin{array}{c}\text { BssHII } \\
\text { SfiI }\end{array}$ & $\begin{array}{c}\text { NruI } \\
\text { Sfi I }\end{array}$ & $\begin{array}{c}\text { MluI } \\
\text { SfII }\end{array}$ & $\begin{array}{c}\text { MluI } \\
\text { BssHII }\end{array}$ & $\begin{array}{l}\text { MluI } \\
\text { SacII }\end{array}$ & $\begin{array}{c}\text { SfiI } \\
\text { SacII }\end{array}$ & $\begin{array}{l}\text { MluI } \\
\text { NruI }\end{array}$ & $\begin{array}{c}\text { NotI } \\
\text { Sfi I }\end{array}$ \\
\hline metH & $\begin{array}{l}140 \\
165 \\
300\end{array}$ & $\begin{array}{l}65 \\
85\end{array}$ & $\begin{array}{l}140 \\
165 \\
300\end{array}$ & $\begin{array}{l}140 \\
240 \\
300\end{array}$ & $\begin{array}{l}140 \\
240 \\
300\end{array}$ & 140 & $\begin{array}{r}60 \\
100 \\
105 \\
130\end{array}$ & $\begin{array}{l}140 \\
165 \\
320 \\
345\end{array}$ \\
\hline CF63 & 35 & $\begin{array}{l}30 \\
55\end{array}$ & $\begin{array}{l}35 \\
60\end{array}$ & 100 & 100 & 35 & 55 & $\begin{array}{r}35 \\
60 \\
140\end{array}$ \\
\hline $3.11 \mathrm{H} 3$ & 980 & $\begin{array}{l}550 \\
720\end{array}$ & 1000 & 920 & 920 & 980 & 720 & ND \\
\hline
\end{tabular}

Note. As in Table 1, the smallest fragments represent complete digests with both enzymes, the larger fragments presumably represent partial digest products with one or both enzymes.

screened with metH or CF63. This implies that the sites for these enzymes are clustered and may represent HTF (HpaII Tiny Fragment) islands (Bird, 1986). There appear to be three such islands in the vicinity of met and CF63, as shown by double digests of any of these three enzymes with MluI. These double digests cleave the primary 240 -kb BssHII, SacII, and NaeI bands to $140-\mathrm{kb}$ bands detected by metH and $100-\mathrm{kb}$ bands detected by CF63. The 560-kb $S f$ I partial digestion fragment is cleaved to $300 \mathrm{~kb}$ by BssHII, SacII, and NaeI in the same manner as that described for MluI and SfiI above. This is explained by one of the MluI sites being in the same cluster as a SacII, BssHII, and NaeI site, as shown in Fig. 3D. Combining Figs. $3 \mathrm{C}$ and $3 \mathrm{D}$, the map shown in $3 \mathrm{E}$ is obtained. The NotI site discussed in Fig. 1 can be added to this map by lining up the 140- and 25-kb $S f$ I fragments with those in Fig. $3 \mathrm{E}$. This places the 420 kb $S f I$ fragment which contains the NotI site to the left of metH. The other end of the NotI fragment and the MluI fragment containing CF63 are shown on the map in Fig. 3F.

Since CF63 represents a defined jump in the $3^{\prime}$ direction from met, the orientation of the met map relative to CF and J3.11 can also be determined. We (Collins et al., 1987a) and others (White et al., 1986) have previously noted the presence of a polymorphic NotI site 3 ' to met which is present (Fig. $3 F$ ) in about $10 \%$ of chromosomes. When this site is present, met appears on a $470-\mathrm{kb}$ NotI fragment rather than on the more usual $850 \mathrm{~kb}$. The sequence XV-2c cloned by Estivill et al. (1987), which by linkage analysis must be closer to CF than is met, lies on a 350-kb NotI fragment in chromosomes with the polymorphic NotI site and on an $820-\mathrm{kb}$ fragment (which we size at $850 \mathrm{~kb}$ ) in chromosomes lacking this site. This indicates that

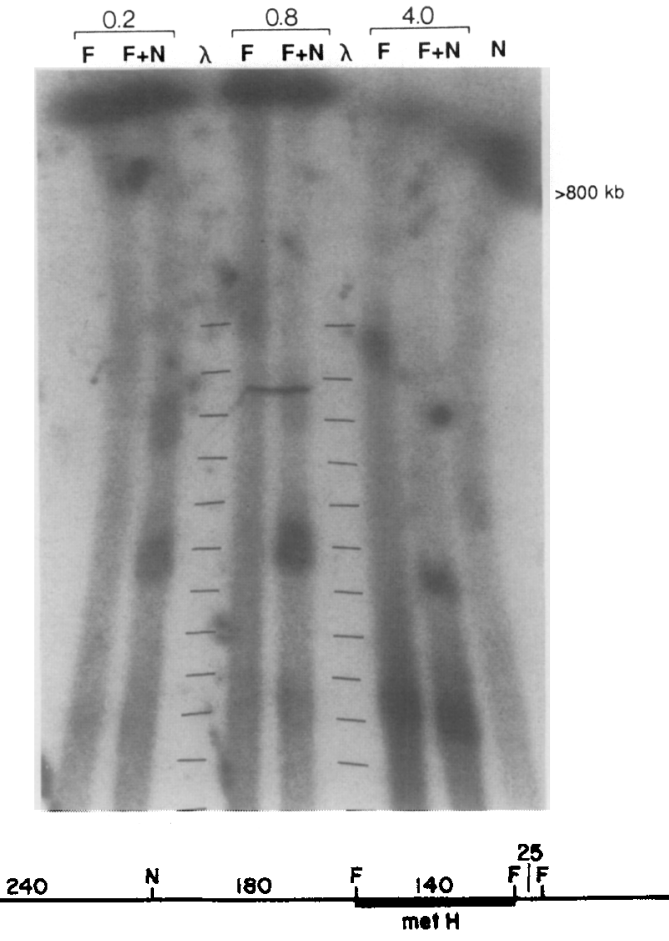

FIG. 1. Genomic digests of lymphoblastoid DNA with $S f I$ I (F), $\mathrm{SfII}+\operatorname{NotI}(\mathrm{F}+\mathrm{N})$, or $\operatorname{NotI}(\mathrm{N})$, run on an OFAGE gel with $30-\mathrm{s}$ pulses for $25 \mathrm{~h}$. All NotI digests were carried out using $4 \mathrm{U} / \mu \mathrm{g}$ DNA to ensure complete digestion, while $S f i$ I concentration was varied to give different degrees of partial digestions. From left to right, the $S f \mathrm{I}$ concentrations are $0.2 \mathrm{U} / \mu \mathrm{g}$ DNA, $0.8 \mathrm{U} / \mu \mathrm{g}$ DNA, and $4.0 \mathrm{U} / \mu \mathrm{g}$ DNA. Markers are drawn in $(\lambda)$ and consist of concatenated $\lambda c I 857$, which are multiples of $48.5 \mathrm{~kb}$. Notice the 560 -kb $S f i$ fragment which is cleaved to $320 \mathrm{~kb}$ by NotI (compare F to F $+\mathrm{N}$ in the 4.0 set). Below is the $S$ fil/NotI map constructed from the data generated from the blot, illustrating the positions of the 420 - and $25-\mathrm{kb}$ Sf I fragments which flank metH, and the NotI site located in the 420 -kb fragment. There is probably an additional NotI site about $140 \mathrm{~kb}$ to the left of this, because of the $460 / 485 \mathrm{~kb}$ doublet in the $0.2 \mathrm{~F}+\mathrm{N}$ lane, but this has not yet been confirmed on other blots. 


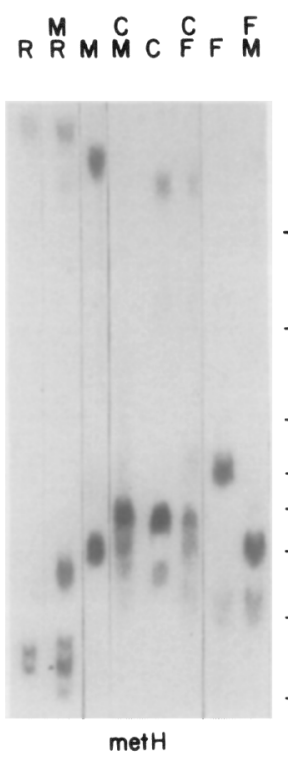

B

$R \stackrel{M}{R} \stackrel{C}{M} \underset{M}{C} \stackrel{C}{F} F \stackrel{F}{M}$

C
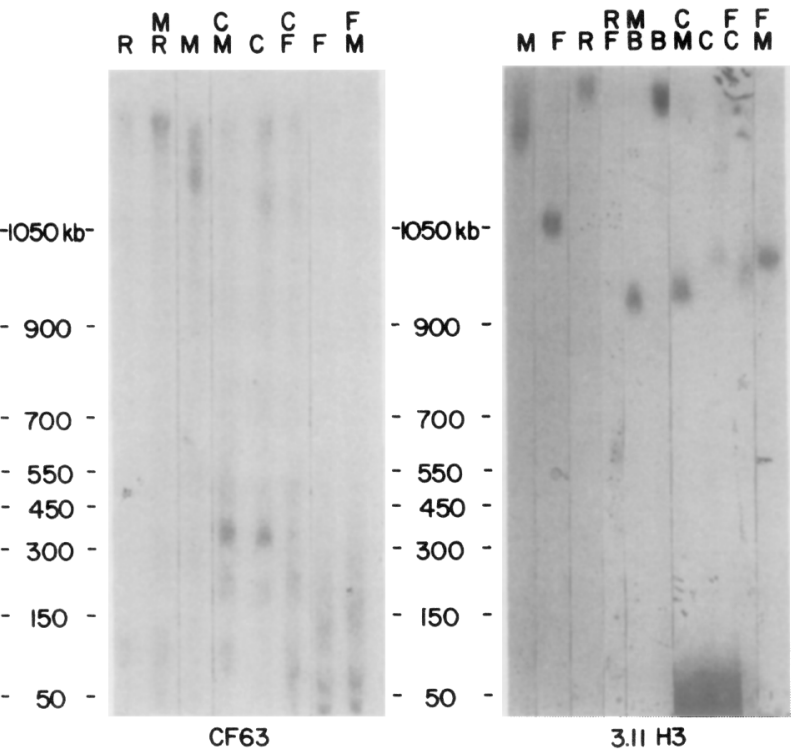

FIG. 2. Lanes from a FIGE Southern blot of lymphoblastoid DNA with combinations of the enzymes BssHII (B), SacII (C), SfiI (F), MluI (M), and NruI (R). (A and B) Probes were metH and CF63, respectively, and both probes are shown hybridizing to the same NruI and SacII fragments, but different MluI and Sfi I fragments. (C) Lanes from the same blot are shown after probing with 3.11H3. As is seen here, there are no fragments on this blot which hybridize to both $3.11 \mathrm{H} 3$ and either of the other two probes.

$\mathrm{XV}-2 \mathrm{c}$ must lie on the $3^{\prime}$ side of met. Since linkage analysis places these markers in the order met-[XV2c-CF]-J3.11 (Beaudet et al., 1986; Estivill et al., 1987), this proves that CF and J3.11 also lie on the $3^{\prime}$ side of met. Such a conclusion is consistent with other data based on a chromosomal rearrangement within the met gene in the MNNG-HOS cell line (Scambler et al., 1986).

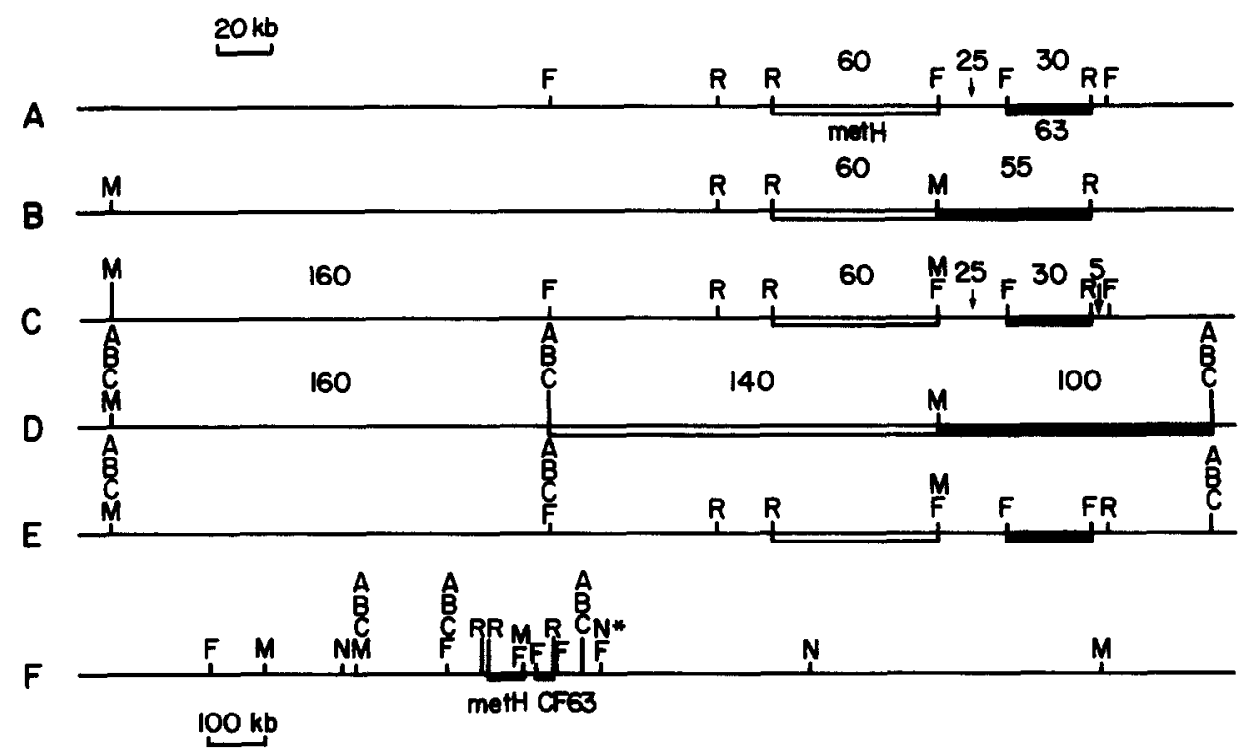

FIG. 3. Construction of metH/CF63 regional map. (A) The map generated by digests with $N r u I$ (R), SfiI (F), and NruI + SfiI; (B) generated from NruI and MluI (M); (C) from MluI and Sfi I; (D) from MluI combined with any of the three enzymes NaeI (A), BssHII (B), or SacII (C). Superimposing maps A, B, C, and D on each other gives the map shown in $\mathbf{E}$. A composite map of the region, shown in $\mathbf{F}$, includes NotI sites indicated in Fig. 1, as well as the $S f I$ sites determined by partial digests. $\mathrm{N}^{*}$ is a polymorphic NotI site. Numbers above maps are sizes in kilobases of fragments. 


\section{D7S8 Regional Map}

The ground work of this map is based on the double digestion product of $\mathrm{SfII}$ and $\mathrm{NruI}$ (Fig. $2 \mathrm{C}$ ). These two enzymes yield a fragment of $550 \mathrm{~kb}$ from an $S f \mathrm{I}$ fragment of $1050 \mathrm{~kb}$ and an $N r u I$ fragment of $1700 \mathrm{~kb}$. NruI combined with MluI cuts the 1150-kb MluI fragment into a $720-\mathrm{kb}$ fragment, SacII plus $M l u I$ shortens the 1000-kb SacII fragment to $920 \mathrm{~kb}$, and $S a c I I$ and $S f i$ result in a $970-k b$ fragment. (These sizes were deduced primarily from OFAGE or Pulsaphor blots, which can separate fragments in this range better than can the FIGE blot shown in Fig. 2C). The map consistent with these data is shown in Fig. 4. This also includes other data from Tables 1 and 2, including restriction sites for partial cleavage products, as for NruI and SfiI.

\section{Joining of the Maps}

To link the two maps, MluI partial digests were analyzed using a long pulse time to resolve fragments as large as $3000 \mathrm{~kb}$. To construct these blots we found it necessary to run partial digests over a wide range of enzyme concentrations, and often to correlate the results of more than one experiment. Two examples of partial MluI blots are shown in Fig. 5. When the blots were probed with metH, a complete digest band of 300 $\mathrm{kb}$ was seen, as well as partial bands of 460,1250 , and $2250 \mathrm{~kb}$. Reprobing with $3.11 \mathrm{H} 3$ gives partial bands at 1950 and $2250 \mathrm{~kb}$ in addition to the $1000-\mathrm{kb}$ primary band. These patterns are consistent with a map in which a $300-\mathrm{kb}$ metH and a $1000-\mathrm{kb} 3.11 \mathrm{H} 3 \mathrm{MluI}$ fragment are separated by a $950-\mathrm{kb} M l u I$ fragment containing CF63, as shown in Fig. 5. In confirmation of this conclusion, CF63 does reside on a $950-\mathrm{kb} M l u \mathrm{I}$ fragment (not well shown in Fig. 2B, but visible in other OFAGE and FIGE blots which are not shown). Partial NruI digests also demonstrate that metH and $3.11 \mathrm{H} 3$ detect the same $1815-\mathrm{kb} \mathrm{NruI}$ fragment. When this information is combined with the partial MluI data in Fig. 5, the final map in Fig. 6 is generated. The orientation of the D7S8 regional map relative to the met-CF63 map must be as shown; the al- ternative orientation could not explain the $M l u \mathrm{I}$ and NruI results.

\section{DISCUSSION}

Locating of a disease gene by "reverse genetics" requires one to move from a primary genetic map, generated by linkage analysis, to a physical map which can be used to delimit the DNA region within which the gene must reside. While the genetic map suggests the size of the physical region by the relationship of $1 \mathrm{cM} \cong 1000 \mathrm{~kb}$, there can be marked local deviations from this correspondence due to nonlinearity of recombination rates along a chromosome. In this study we have used the two markers met and J3.11, which are known to be tightly linked to CF, as well as a jumping clone derived from met (CF63), to construct a long-range restriction map of the CF region covering approximately $3000 \mathrm{~kb}$ on chromosome 7. The summary map is shown in Fig. 6.

A few caveats about physical mapping of large chromosomal regions should be kept in mind. The recognition sites for most of the enzymes used (except $S f I$ ) contain CpG sequences, and methylation of the cytosine residues can potentially prevent restriction (Smith et al., 1987b). Any variation in the methylation of these sites from cell line to cell line or tissue to tissue could result in a difference in restriction fragment lengths and thus in the map. Strictly speaking, the map presented is that for B-cell line 3.1.0 and may differ for other cell lines. Partial methylation may result in incomplete digestion, even with large quantities of restriction enzyme. Examples are the two MluI sites between metH and 3.11H3. Incomplete cutting at these MluI sites leads to the strong signal for the 2250-kb fragment in Fig. 5 .

A related issue is that in diploid cell lines, the possibility of restriction site polymorphism must be considered when two bands are detected by a single probe in a complete digest, especially if the intensities of the two bands are similar. An example is the polymorphic NotI site shown in Fig. 6. Without studies of familial inheritance, it may be impossible to distinguish this
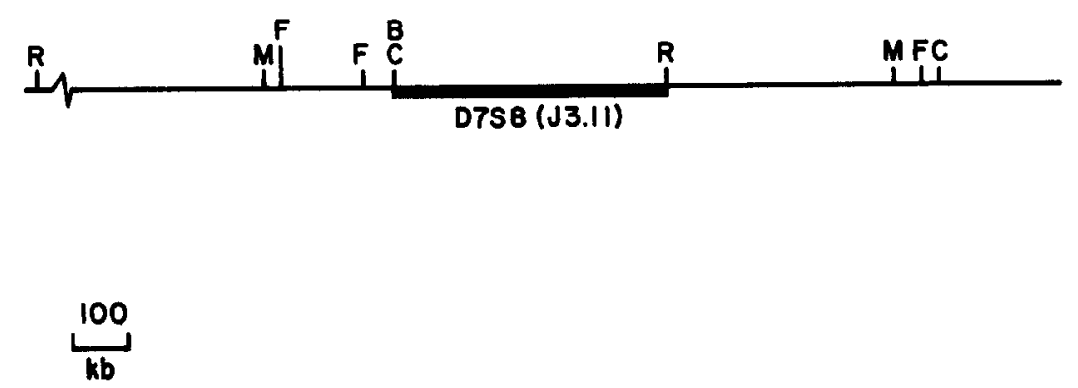

FIG. 4. D7S8 regional map constructed from single and double digests with BssHII (B), SacII (C), SfI (F), MluI (M), and NruI (R). Sizes of fragments from these digests are listed in Table 1 and 2. 

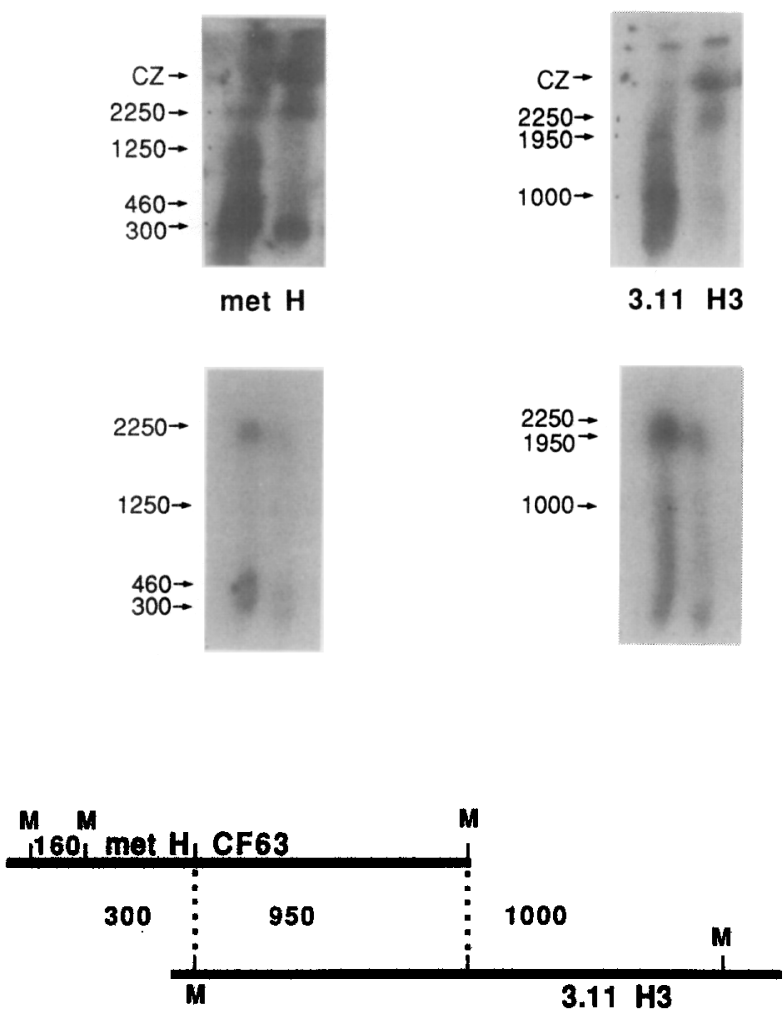

FIG. 5. MluI partial digest Southern blots probed sequentially with metH and 3.11H3. The upper panel, which is from a gel run on an LKB Pulsaphor as described by Smith et al. (1987a), resolves intermediate partial fragments, including bands at 460 and $1250 \mathrm{~kb}$ for metH and at 1000 and $1950 \mathrm{~kb}$ for $3.11 \mathrm{H} 3$. The lower panel, also from a Pulsaphor, but run as described under Materials and Methods, does not show some of these intermediate fragments but clearly shows both probes hybridizing to the same $2250-\mathrm{kb}$ partial MluI fragment. In both blots the lane on the left is a somewhat more complete digest than the lane on the right, though both are intentional partials. The apparent signal at the lower end of the size range with probe $3.11 \mathrm{H} 3$ in the lower panel is an artifact due to nonspecific hybridization to small amounts of degraded DNA in these samples. Below is a map consistent with the data from the two blots in which metH and $3.11 \mathrm{H} 3$ can be linked together. result from partial digestion due to methylation. The overall map will not, however be affected so long as the same cell line is used throughout.

A final caveat is that the sizes of the fragments reported in Tables 1 and 2 must be considered to have a potential error of at least $10 \%$. Sizing of PFGE bands is quite sensitive to the amount of DNA per lane (Collins et al., 1987b); while we attempted to keep the DNA per lane under $3 \mu \mathrm{g}$, some variation in the size of a fragment from gel to gel was often seen. In our experience, one must be particularly careful in sizing DNA fragments larger than $800 \mathrm{~kb}$ on FIGE gels; as also noted by others (Ellis et al., 1987), above this range the relationship of fragment size to mobility breaks down.

The map in Fig. 6 indicates that met and J3.11 are between 1300 and $1800 \mathrm{~kb}$ apart, which is in reasonable agreement with their genetic distance of about 2 $\mathrm{cM}$. The CF gene must reside within this region. Two clusters of sites, so-called HTF islands (Bird, 1986), appear in this interval, one just $3^{\prime}$ to met, and the other about $400 \mathrm{~kb}$ closer to J3.11. This latter island has recently been cloned by Estivill et al. (1987) and contains sequences in strong disequilibrium with the $\mathrm{CF}$ gene. The suggestion that the CF transcript itself is encoded in this segment has not, however, been confirmed. There is, of course, no reason why the CF gene, which is expressed in a highly tissue-specific manner, need be associated with an HTF island. The physical map in Fig. 6 can be of considerable utility in ordering additional cloned DNA segments from this region. Coupled with fine linkage analysis in CF families in which recombinations between met and CF or CF and J3.11 have occurred, physical mapping should allow the narrowing of the actual gene location to a region of $200-300 \mathrm{~kb}$. A region of this size would be small enough to clone in overlapping cosmids, which

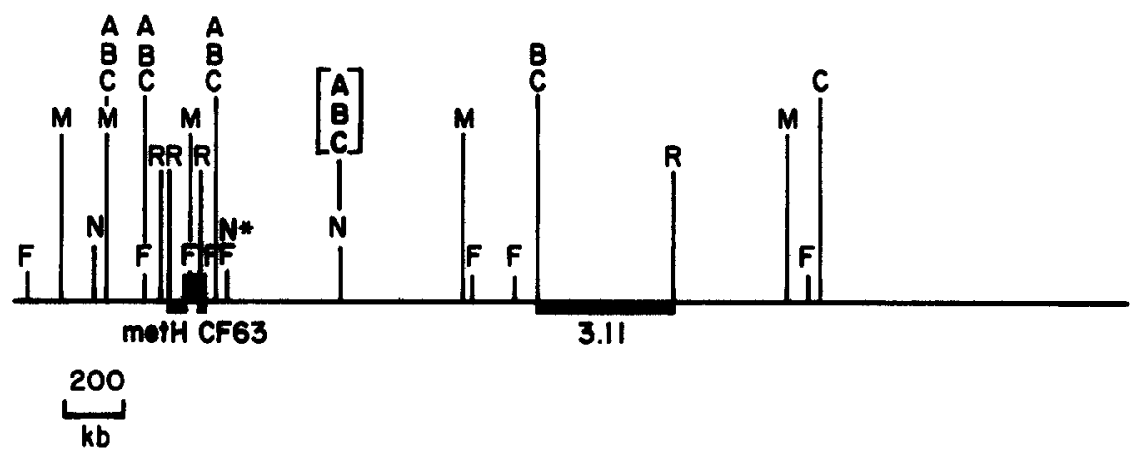

FIG. 6. Composite map linking regional maps of Figs. $3 \mathrm{~F}$ and 4 together. The distance between metH and $3.11 \mathrm{H} 3$ is estimated from this map to be between 1300 and $1800 \mathrm{~kb}$. A, NaeI; B, BssHII; C, SacII; F, SfI I M, MluI; N, NotI; and R, NruI. Additional SfiI, NaeI, BssHII, and SacII sites may be located in the region near the center of the map, but cannot be detected by the probes used. In brackets are the NaeI, BssHII, and SacII sites reported by Estivill et al. (1987) to be present close to the NotI site in the center of the map, which is the location of the XV-2c and CS-7 probes they have derived. The sites in brackets do not cut in the B-lymphoblast cell line used for our mapping data. 
could be screened exhaustively for candidate transcripts. With this strategy there is good reason to be optimistic that in the near future the cloned CF gene will be in hand.

\section{ACKNOWLEDGMENTS}

We thank J. Weber for expert technical assistance, and D. Rennert for preparing the manuscript. This work was partially supported by a grant from the American Lung Association to M.C.I. and by Grant GM34960 from the National Institutes of Health to F.S.C., who also gratefully acknowledges support from the Howard Hughes Medical Institute. C.L.S. was supported by DOE Grant DE-FG02-87ER-GD582, NIH Grant CA 39782, and a grant from LKB-Pharmacia Produkter AB.

\section{REFERENCES}

1. Beaudet, A., Bowcock, A., Buchwald, M., CavalliSforza, L., Farrall, M., KING, M.-C., Klinger, K., LALOUEL, J-M., LATHROP, G., NAYLOR, S., OTT, J., TSUI, L-C., WaINWRight, B., Watkins, P., White, R., and William. soN, R. (1986). Linkage of cystic fibrosis to two tightly linked DNA markers: Joint report from a collaborative study. Amer. J. Hum. Genet. 39: 681-693.

2. BiRD, A. P. (1986). CpG-rich islands and the function of DNA methylation. Nature (London) 321: 209-213.

3. BURMEISTER, M., AND LeHRACH, H. (1986). Long-range restriction map around the Duchenne muscular dystrophy gene. Nature (London) 324: 582-585.

4. Cantor, C. R., Warburton, P., SMith, C. L., and GaAl, A. (1986). Voltage ramp pulsed field gel electrophoresis separation of large DNA molecules. In "Electrophoresis '86" (M. Dunn, Ed.), pp. 161-171, VCH Publishers, Weinheim.

5. Carle, G. F., AND Olson, M. V. (1984). Separation of chromosomal DNA molecules from yeast by orthogonal-field-alternation gel electrophoresis. Nucleic Acids Res. 12: 5647-5664.

6. Carle, G. F., Frank, M., ANd Olson, M. V. (1986). Electrophoretic separations of large DNA molecules by periodic inversion of the electric field. Science 232: 65-68.

7. ChU, G., Vollrath, D., AND Davis, R. W. (1986). Separation of large DNA molecules by contour-clamped homogenous electric fields. Science 234: 1582-1585.

8. ChURCH, G. M., AND GILBERT, W. (1984). Genomic sequencing. Proc. Natl. Acad, Sci. USA 81: 1991-1995.

9. Collins, F. S., AND Weissman, S. M. (1984). Directional cloning of DNA fragments at a large distance from an initial probe: A circularization method. Proc. Natl. Acad. Sci. USA 81: 6812-6816.

10. Collins, F. S., Drumm, M. L., Cole, J. L., Lockwood, W. K., VANDE WoUde, G. F., AND IANNUZZI, M. C. (1987a). Construction of a general human chromosome jumping library, with application to cystic fibrosis. Science 235: 1046-1049.

11. Collins, F. S., COLE, J. L., Lockwood, W. K., AND IANNUZZI, M. C. (1987b). The deletion in both common types of hereditary persistence of fetal hemoglobin is approximately $105 \mathrm{ki}$ lobases. Blood 70: 1797-1803.

12. Dean, M., O'Connell, P., Leppert, M., Park, M., Amos, J. A., PhIllips, D. G., White, R., AND Vande Woude, G. F. (1987). Three additional DNA polymorphisms in the met gene and D7S8 locus: Use in prenatal diagnosis of cystic fibrosis. $J$. Pediatrics 111: 490-495.
13. Ellis, T. H. N., Cleary, W. G., Burcham, K. W. G., and BoweN, B. A. (1987). Ramped field inversion gel electrophoresis: A cautionary note. Nucleic Acids Res. 15: 5489.

14. Estivill, X., Farrall, M., Scambler, P. J., Beli, G. M., Hawley, K. M. F., Lench, N. J., Bates, G. P., Kruyer, H. C., Frederick, P. A., Stanier, P., Watson, E. K., WilLIAMSON, R., AND WAINWRIGHT, B. J. (1987). A candidate for the cystic fibrosis locus isolated by selection for methylationfree islands. Nature (London) 236: 840-845.

15. Feinderc, A. P., And Vogelstein, B. (1984). A technique for radiolabeling DNA restriction fragments to high specific activity. Anal. Biochem. 137: 266-267.

16. Friend, S. H., Bernards, R., RogelJ, S., Weinberg, R. A., RAPAPORT, J. M., AlbERT, D. M., AND DRYJA, T. P. (1986). A human DNA segment with properties of the gene that predisposes to retinoblastoma and osteosarcoma. Nature (London) 232: $643-646$.

17. Frizzeld, R. A., RechKemmer, G., AND Shoemaker, R. L. (1986). Altered regulation of airway epithelial cell chloride channels in cystic fibrosis. Science 233: 558-560.

18. Herrmann, B., Bucan, M., Mains, P. E., Frischauf, A-M., SILVER, L. M., AND LEHRACH, H. (1986). Genetic analysis of the proximal portion of the mouse $t$ complex: Evidence for a second inversion within $t$ haplotypes. Cell 44: 469-476.

19. Kenwrick, S., Patterson, M., Spear, A., Fischieck, K., AND DAvIES, K. (1987). Molecular analysis of the Duchenne muscular dystrophy region using pulsed field gel electrophoresis. Cell 48: 351-357.

20. Lathrop, G. M., Farrall, M., O'Connell, P., WainWRIGHT, B., LEPPERT, M., NAKAMURA, Y., LENCH, N., Kruyer, H., Dean, M., Park, M., Vande Woude, G., LALOUEL, J.-M., WILLIAMSON, R., AND WHITE, R. (1988). Refined linkage map of chromosome 7 in the region of the cystic fibrosis gene. Amer. J. Hum. Genet. 42: 38-44.

21. Lawrance, S. K., Smith, C. L., Srivastava, R., Cantor, C. R., AND WEISSMAN, S. M. (1987). Megabase scale mapping of the HLA gene complex by pulsed field gel electrophoresis. Science 235: 1387-1390.

22. LITT, M., AND WHITE, R. L. (1985). A highly polymorphic locus in human DNA revealed by cosmid-derived probes. Proc. Natl. Acad. Sci. USA 82: 6206-6210.

23. LLOYD-STILL, J. D. (1983). "Textbook of Cystic Fibrosis," John Wright-PSG Inc., Boston.

24. Maniatis, T., Fritsch, E. F., and SAmbrooK, J. (1982), "Molecular Cloning. A Laboratory Manual," Cold Spring Harbor Laboratory, Cold Spring Harbor, NY.

25. Monaco, A. P., Neve, R. L., Colletti-Feener, C., BertelSON, C. J., KuRNIT, D. M., AND KunKer, L. M. (1986). Isolation of candidate cDNAs for portions of the Duchenne muscular dystrophy gene. Nature (London) 232: 646-650.

26. ORKIN, S. H. (1986). Reverse genetics and human disease. Cell 47: 845-850.

27. PoustKa, A., AND LeHraCh, H. (1986). Jumping libraries and linking libraries: The next generation of molecular tools in mammalian genetics. Trends Genet. 2: 174-179.

28. PoustKa, A., Pohl, T. M., Barlow, D. P., Frischauf, A-M., AND LEHRACH, H. (1987). Construction and use of chromosome jumping libraries from NotI-digested DNA. Nature (London) 325: 353-355.

29. Royer-Pokora, B., Kunkel, L. M., Monaco, A. P., Goff, S. C., Newburger, P. E., Baehner, R. L., Cole, F. S., CURNUTTE, J. T., AND ORKIN, S. H. (1986). Cloning the gene for an inherited human disorder-chronic granulomatous diseaseon the basis of its chromosomal location. Nature (London) 322: $32-38$. 
30. RudDLE, F. (1984). Reverse genetics and beyond. Amer. J. Hum. Genet. 36: 944-953.

31. Scambler, P. J., LAW, H-Y., Williamson, R., and Cooper, C. S. (1986). Chromosome-mediated gene transfer of six DNA markers linked to the cystic fibrosis locus on human chromosome seven. Nucleic Acids Res. 14: 7159-7174.

32. Schwartz, D. C., Saffran, W., Welsh, J., HaAs, R., GoldENBERG, M., AND CANTOR, C. R. (1983). New techniques for purifying large DNAs and studying their properties and packaging. Cold Spring Harbor Symp. Quant. Biol. 47: 189-195.

33. Schwartz, D. C., AND CANTOR, C. R. (1984). Separation of yeast chromosome-sized DNAs by pulsed field gradient gel electrophoresis. Cell 37: 67-75.

34. Smith, C. L., Warburton, P. E., GaAl, A., and Cantor, C. R. (1986). Analysis of genome organization and rearrangements by pulsed field gradient gel electrophoresis. In "Genetic Engineering" (J. K. Setlow and A. Hollaender, Eds.), Vol. 8, pp. 45-70, Plenum Press, New York.

35. SMith, C. L., AND CaNTor, C. R. (1987). Purification, specific fragmentation, and separation of large DNA molecules. In "Methods in Enzymology" (R. Wu, Ed.), Vol. 155, Academic Press, San Diego.

36. Smith, C. L., Matsumoto, T., Niwa, O., Klco, S., Fan, J. B., YANAGIDA, M., AND CANTOR, C. R. (1987a). A molecular karyotype for Schizosaccharomyces pombe by pulsed field gel electrophoresis. Nucleic Acids Res. 15: 4481-4490.

37. SMith, C. L., Lawrance, S. K., Gillespie, G. A., CaNtor, C. R., Weissman, S. M., AND Collins, F. S. (1987b). Strategies for mapping and cloning macro-regions of mammalian genomes. In "Methods in Enzymology" (M. M. Gottesman, Ed.), Vol. 151, pp. 461-489, Academic Press, San Diego.
38. TAussig, L. M. (1984). "Cystic Fibrosis," Thieme-Stratton, New York.

39. Tsui, L-C., Buchwald, M., Barker, D., Bramer, J. C., Knowlton, R., Schumm, J. W., Eiberg, H., MOHR, J., KeNNedy, D., Plavis, N., Zsiga, M., Markiewicz, D., Akots, G., Brown, V., Helms, C., Gravius, T., Parker, C., ReDIKER, K., AND DONIS-KELleR, H. (1985). Cystic fibrosis locus defined by a genetically linked polymorphic DNA marker. Science 230: 1054-1057.

40. Van OMMen, G. J. B., Verkerk, J. M. H., Hofker, M. H., Monaco, A. P., Kunkel, L. M., Ray, P., Worton, R., WieRINGA, B., BAKker, E., AND PEARson, P. L. (1986). A physical map of 4 million bp around the Duchenne muscular dystrophy gene on the human X-chromosome. Cell 47: 499-504.

41. Wainwright, B. J., Scambler, P. J., SchmidtKe, J., Watson, E. A., Law, H-Y., Farrall, M., Cooke, H. J., Eiberg, H., AND WILLIAMSON, R. (1985). Localization of cystic fibrosis locus to human chromosome 7cen-q22. Nature (London) 318: 384-386.

42. WELSH, M. J., AND LIEDTKE, C. M. (1986). Chloride and potassium channels in cystic fibrosis airway epithelia. Nature (Iondon) 322: 467-470.

43. White, R., Woodward, S., LePpert, M., O'Connell, P., Hoff, M., Herbst, J., Lalouel, J. M., Dean, M., and Vande WOUDE, G. F. (1985). A closely linked marker for cystic $\mathrm{f}$ brosis. Nature (London) 318: 382-384.

44. White, R., LePpert, M., O'CONNELl, P., NAKAMURA, Y., Julien, C., WoOdWard, S., Silva, A., WolfF, R., LATHROP, M., AND LaLOUEL, J-M. (1986). Construction of human genetic linkage maps. I. Progress and perspectives. Cold Spring Harbor Symp. Quant. Biol. 510: 29-38. 